\title{
Regulation of adiponectin and its receptors in rat ovary by human chorionic gonadotrophin treatment and potential involvement of adiponectin in granulosa cell steroidogenesis
}

\author{
Christine Chabrolle ${ }^{1,2}$, Lucie Tosca ${ }^{1}$ and Joëlle Dupont ${ }^{1}$ \\ ${ }^{1}$ Unité de Physiologie de la Reproduction et des Comportements, Institut National de la Recherche Agronomique, \\ 37380 Nouzilly, France and ${ }^{2}$ Unité d'Endocrinologie, Diabétologie, Maladies Métaboliques, CHRU Bretonneau, \\ 37000 Tours, France \\ Correspondence should be addressed to J Dupont; Email: jdupont@tours.inra.fr
}

\begin{abstract}
In mammals, adiponectin and its receptors (AdipoR1 and AdipoR2) mRNAs are expressed in various tissues. However, the cellular expression and the role of adiponectin system have never been investigated in rat ovary. Here, we report the presence of adiponectin, AdipoR1 and AdipoR2 in rat ovaries, and we have investigated its role in granulosa cells. Using RT-PCR and western blot, we show that the mRNAs and proteins for adiponectin, AdipoR1 and AdipoR2 are found in the ovaries.

Immunohistochemistry localized adiponectin, AdipoR1 and AdipoR2 in theca-interstitial T-I cells, corpus luteum, oocyte and less abundantly in granulosa cells. In the KGN human granulosa cell line, adiponectin mRNA and protein were undetectable; AdipoR2 was weakly expressed, whereas AdipoR1 was clearly present. Human chorionic gonadotrophin (hCG) injection (48 h) after pregnant mare serum gonadotrophin (PMSG) injection $(24 \mathrm{~h})$ in immature rats increased the level of adiponectin (protein) by about threefold $(P<0.05)$ and those of AdipoR1 by threefold (mRNA, $P<0.05)$ and 1.5 -fold (protein, $P<0.05)$ in ovary, whereas the mRNA and protein levels of AdipoR2 were unchanged. Interestingly, hCG injection (48 h) after the PMSG treatment (24 h) decreased plasma adiponectin levels and increased insulin plasma levels. In vitro in primary rat granulosa cells, human adiponectin recombinant $(5 \mu \mathrm{g} / \mathrm{ml})$ in the presence or absence of follicle-stimulating hormone $\left(10^{-8} \mathrm{M}, 48 \mathrm{~h}\right)$ had no effect on the steroidogenesis. However, it increased progesterone secretion $(P<0.05)$ by about twofold and oestradiol production $(P<$ $0.05)$ by about 1.6-fold in response to insulin-like growth factor-I (IGF-I) $\left(10^{-8} \mathrm{M}\right)$. Furthermore, it improved IGF-I-induced IGF-I receptor- $\beta$ subunit tyrosine phosphorylation and ERK1/2 phosphorylation. In basal state, human adiponectin recombinant also increased rapidly but transiently the ERK1/2, p38 and Akt phosphorylations, whereas it increased more lately the adenosine 5'-monophosphate-activated protein kinase (AMPK) phosphorylation. Thus, AdipoR1 and AdipoR2 are regulated by hCG treatment in rat ovary and adiponectin enhances IGF-I-induced steroidogenesis in granulosa cells.

Reproduction (2007) 133 719-731
\end{abstract}

\section{Introduction}

Adiponectin (also known as apM1, AdipoQ, Gbp28 and Acrp30) is one of the adipocyte-derived factors (Scherer et al. 1995, Maeda et al. 1996). It is present as a multimer at high concentrations in the circulation $(5-25 \mu \mathrm{g} / \mathrm{ml}$ in humans; Pajvani \& Scherer 2003). In obese and type 2 diabetic humans, plasma adiponectin is strongly reduced, suggesting that circulating adiponectin may be related to the development of insulin resistance (Kadowaki \& Yamauchi 2005). Circulating levels of adiponectin are about two to three times higher in females than in males (Combs et al. 2003). However, the modulatory role exerted by oestrogens is unclear.
Indeed, ovariectomy in adult mice increases the levels of plasma adiponectin and oestrogens suppress adiponectin expression in mice and 3T3-L1 adipocytes (Combs et al. 2003). Conversely, a downregulatory role of testosterone on adiponectin secretion has already been observed in humans (Lanfranco et al. 2004). Structurally, adiponectin is related to the complement 1q family and contains a carboxy-terminal globular domain and an amino-terminal collagenous domain (Scherer et al. 1995). The globular domain is able to induce several biological effects of adiponectin (Fruebis et al. 2001).

Adiponectin receptor (AdipoR) 1 and 2 have been identified in different species, including humans, rodents 
(Yamauchi et al. 2003), pigs (Lord et al. 2005) and chicken (Ramachandran et al. 2006, Chabrolle et al. in press). Adiponectin and its receptors (AdipoR1 and AdipoR2) contain seven transmembrane domains (Ouchi et al. 2001), but they are structurally and functionally different from $G$ protein-coupled receptors (GPCR). Indeed, unlike GPCR, the N-terminal end of AdipoR1 and AdipoR2 is in the intracellular domain and the C-terminal ends are in the extracellular domain (Yamauchi et al. 2003). AdipoR1 is abundantly expressed in mouse skeletal muscle, whereas AdipoR2 is predominantly found in liver (Yamauchi et al. 2003). In mouse, the expression of the AdipoR1 and AdipoR2 is inversely regulated by insulin in physiological and pathophysiological states, such as fasting/refeeding, insulin deficiency and hyperinsulinaemia models (Tsuchida et al. 2004). Both AdipoR1 and AdipoR2 serve as receptors for globular and full-length adiponectin. They mediate increased AMPK (adenosine 5'monophosphate-activated protein kinase), mitogen-activated kinase (MAPK) and peroxisome proliferator-activated receptor (PPAR)- $\alpha$ ligand activity in response to adiponectin (Yamauchi et al. 2003).

The metabolic effects of adiponectin are numerous. Adiponectin has been shown to augment lipid oxidation in skeletal muscle and myocytes (Fruebis et al. 2001, Yamauchi et al. 2001) and to reduce hepatic glucose production in liver and hepatocytes (Berg et al. 2001, Combs et al. 2001). Adiponectin also increases sensitivity to insulin and vasodilatation. It also possesses antiatherogenic activities (for review see Kadowaki \& Yamauchi 2005). Adiponectin could also be involved in the regulations of some reproductive functions. In women with polycystic ovarian syndrome (PCOS), plasma adiponectin is significantly decreased independently of obesity (Ardawi \& Rouzi 2005). PCOS is a disorder that is characterized by excess androgen production and infertility (Rotterdam ESHRE/ASRM 2004). Adiponectin and AdipoR2 are localized in both human and rat placenta (Caminos et al. 2005). Placental adiponectin mRNA expression is increased during pregnancy in rat, whereas AdipoR2 has the contrary pattern (Caminos et al. 2005). Adiponectin, AdipoR1 and AdipoR2 are also present in porcine (Lord et al. 2005, Ledoux et al. 2006) and chicken ovaries (Maddineni et al. 2005, Ramachandran et al. 2006). In this latter species, results from our laboratory have shown that adiponectin mRNA expression is 30-fold higher in theca than in granulosa cells (Chabrolle et al. in press). Moreover, human recombinant adiponectin increased AMPK Thr172 phosphorylation in primary chicken granulosa cells (Chabrolle et al. in press). In porcine ovary, adiponectin alone or in combination with insulin and gonadotrophins induced gene expression resulting in prostaglandin and vascular endothelial growth factor (VEGF) synthesis in granulosa cells (Ledoux et al. 2006). These results are similar to those observed during the peri-ovulatory remodelling of the ovarian follicle
(Ledoux et al. 2006). Thus, adiponectin could be involved in the regulations of the ovarian functions.

In the present study, we have identified and localized AdipoR1 and AdipoR2 in rat ovary and studied their regulation in terms of mRNA and protein in vivo during the follicular development after PMSG/hCG injection to immature rats. In vitro in rat primary granulosa cells, we have investigated the effects of human recombinant adiponectin on progesterone and oestradiol secretions in the presence or absence of IGF-I and Follicle-stimulating hormone $(\mathrm{FSH})$ and on various signalling pathways (AMPK, MAPK and Akt).

\section{Materials and Methods}

\section{Hormones and reagents}

Pregnant mare serum gonadotrophin (PMSG) and human chorionic gonadotrophin (hCG) used for injections to animals were obtained from Intervet (Angers, France). Purified ovine FSH-20 (oFSH; lot no. AFP-7028D, $4453 \mathrm{IU} / \mathrm{mg}$, FSH activity is equal to 175 times the activity of oFSH-S1) used for culture treatment was a gift from (NIDDK, National Hormone Pituitary Program, Bethesda, MD, USA). Recombinant human insulin-like growth factor-I (IGF-I) was from Sigma. Recombinant human adiponectin produced in the NSO mammalian cell system was obtained from R\&D (Lille, France).

\section{Antibodies}

Antibodies to AdipoR2 (4-39) and AdipoR1 (41-65) were obtained from Phoenix Pharmaceuticals, Inc. (Belmont, CA, USA). Antibody to rat adiponectin was obtained from Abcam (Cambridge, UK). Antibodies to phospho-Akt (Ser 473), Akt, phospho-ERK1/2 (Thr202/Tyr204), phosphop38 (Thr180/Tyr182) and phospho-AMPK- $\alpha$ Thr172 were purchased from New England Biolabs, Inc. (Beverly, MA, USA). Antibody to AMPK $\alpha 1$ was obtained from Upstate Biotechnology, Inc. (Lake, Placid, NY, USA). Antibody to phosphotyrosine proteins (PY20) was from Biosciences (Le Pont de Claix, France). Antibodies to adiponectin (ACRP 30, N20) for immunohistochemistry, ERK2 (C14), IGF-IR (C20) and p38 (C20) were purchased from Santa Cruz Biotechnology (Santa Cruz, CA, USA). Antibodies to StAR and p450scc were generously provided by Dr Dale Buchanan Hales (University of Illinois, Chicago, IL, USA) and $3 \beta \mathrm{HSD}$ by Dr Van Luu-The (CHUL Research Center and Laval University, Canada). Antibody to vinculin was obtained from Sigma. All antibodies were used at 1/1000 dilution in western blotting.

\section{Animals}

All procedures were approved by the Agricultural Agency and the Scientific Research Agency and conducted in accordance with the guidelines for Care 
and Use of Agricultural Animals in Agricultural Research and Teaching.

Immature female rats of the Wistar strain $(n=30)$ were purchased from Janvier Laboratories (Genest St Isle, France). Ovaries were collected from immature (21-dayold) rats that were untreated $(n=6)$ or treated with $25 \mathrm{IU}$ PMSG for $24 \mathrm{~h}$ to induce follicular growth $(n=24)$. Some rats $(n=18)$ received a single i.p. injection of 25 IU hCG after the PMSG treatment to induce ovulation and luteinization, and ovaries were obtained at different intervals $(6 \mathrm{~h}(n=6), 24 \mathrm{~h}(n=6)$ and $48 \mathrm{~h}(n=6)$ after the PMSG treatment) for a measurement by northern blot, immunohistochemistry and western blot analyses.

Other ovaries from immature rats $(n=8)$ treated with PMSG (20 UI, $48 \mathrm{~h}$ ) and then with hCG (5 UI, $24 \mathrm{~h}$ ) were used to collect oocytes, as described by Charreau et al. (1996). The oviducts were dissected out, and oocytes were recovered by oviductal flushing. The cumulus mass surrounding ovulated oocytes was dispersed using $0.1 \%$ hyaluronidase in M2 medium (Ng 1986). The oocytes were then examined under a phase contrast microscope and collected in Trizol reagent for total RNA extraction or in lysis buffer for protein preparation.

\section{Isolation and culture of rat granulosa cells and T-I cells}

Immature female rats were injected subcutaneously with diethylstilboestrol (DES; $1 \mathrm{mg} /$ day) for 3 days. On the third day of DES treatment, the animals were killed and the ovaries removed aseptically. Granulosa cells were harvested by puncturing the follicles, allowing the expulsion of the cells. Cells were recovered by centrifugation and washed with fresh medium. The culture medium used was McCoy's 5A supplemented with $20 \mathrm{mmol} / \mathrm{l}$ Hepes, penicillin $(100 \mathrm{U} / \mathrm{ml})$, streptomycin $(100 \mathrm{mg} / \mathrm{l})$, L-glutamine $(3 \mathrm{mmol} / \mathrm{l}), 0.1 \% \mathrm{BSA}, 50 \mu \mathrm{g} / \mathrm{l}$ insulin, $0.1 \mu \mathrm{mol} / \mathrm{l}$ androstenedione, $5 \mathrm{mg} / \mathrm{l}$ transferrin, $20 \mu \mathrm{g} / \mathrm{l}$ selenium and $5 \%$ FBS. The remaining ovarian tissues were washed thrice with medium 199 containing $25 \mathrm{mmol} / \mathrm{l}$ Hepes $(\mathrm{pH} 7.4)$, L-glutamine $(2 \mathrm{mmol} / \mathrm{l})$, BSA $(0.1 \%)$, penicillin $(100 \mathrm{U} / \mathrm{ml})$ and streptomycin $(100 \mathrm{mg} / \mathrm{l})$ to release remaining granulosa cells. To obtain T-I cells, the ovarian tissue was minced actively and repeatedly and incubated for $60 \mathrm{~min}$ at $37^{\circ} \mathrm{C}$ in the same medium 199, supplemented with collagenase type $1(5.1 \mathrm{mg} / \mathrm{ml})$ plus $10 \mu \mathrm{g} / \mathrm{ml}$ DNase, as described by Duleba et al. (1997). The T-I cells released by this digestion were centrifuged at $250 \mathrm{~g}$ for $5 \mathrm{~min}$ and washed in collagenase-free medium twice to eliminate remaining collagenase. The dispersed cells were then resuspended in the same McCoy's 5A medium used for the culture of the granulosa cells. The cells (granulosa and T-I) were initially cultured for $48 \mathrm{~h}$ without any other treatment and then incubated in fresh culture medium with or without test reagents for the appropriate time. All cultures were performed under a water-saturated atmosphere of $95 \%$ air $/ 5 \% \mathrm{CO}_{2}$ at $37^{\circ} \mathrm{C}$. We used about $30-40$ rats for each culture and we realized at least three independent cultures for each experiment. Moreover, in each experiment, each condition was tested in triplicate or quadruplet.

\section{Culture of KGN cells}

The human ovarian granulosa-like tumour cells (KGN cells) were cultured in a 1:1 mixture of DMEM and Ham's F-12 medium (Invitrogen) supplemented with 10\% FBS, penicillin $(100 \mathrm{U} / \mathrm{ml})$ and streptomycin $(100 \mu \mathrm{g} / \mathrm{ml})$, as previously described by Nishi et al. (2001).

\section{RNA isolation and RT-PCR}

Total RNA was extracted from whole tissue (ovary, liver and muscle), corpus luteum and fresh granulosa cells using Trizol reagent, according to the manufacturer's procedure (Invitrogen). RT-PCR was performed, as described by Tosca et al. (2005), to assay expression of adiponectin, its receptors 1 and 2 in rat ovary, muscle, liver, adipose tissue, fresh granulosa cells and corpus luteum and in human granulosa KGN cells. Specific sets of primer pairs designed to amplify parts of adiponectin, AdipoR1 and AdipoR2 are described in Tables 1 and 2.

Table 1 Rat oligonucleotide primer sequences for RT-PCR amplification.

\begin{tabular}{|c|c|c|}
\hline Primer & Sequence & $\begin{array}{l}\text { Product } \\
\text { size (bp) }\end{array}$ \\
\hline \multicolumn{3}{|l|}{ Adiponectin } \\
\hline Sense & 5'-AATCCTGCCCAGTCATGAAG-3' & 214 \\
\hline Antisense & $5^{\prime}$-СATCTCCTGGGTCACCСТTA- $3^{\prime}$ & \\
\hline \multicolumn{3}{|l|}{ AdipoR1 } \\
\hline Sense & 5'-ATGCCATGGAGAAGATGGAG-3' & 540 \\
\hline Antisense & 5'-ACTGTGCCACAATGATGGCA-3' & \\
\hline \multicolumn{3}{|l|}{ AdipoR2 } \\
\hline Sense & 5'-GGAACTCGAGTGTCACGATG-3' & 720 \\
\hline Antisense & 5'-TGGCAGCCTTCAGGAACCCT-3' & \\
\hline \multicolumn{3}{|l|}{ Actin } \\
\hline Sense & 5'-ACGGAACCACAGTTTATCATC-3' & 188 \\
\hline Antisense & 5'-GTCCCAGTCTTCAACTATACC-3' & \\
\hline
\end{tabular}

Table 2 Human oligonucleotide primer sequences for RT-PCR amplification.

\begin{tabular}{|c|c|c|}
\hline Primer & Sequence & $\begin{array}{l}\text { Product } \\
\text { size (bp) }\end{array}$ \\
\hline \multicolumn{3}{|l|}{ Adiponectin } \\
\hline Sense & 5'-TGGTGAGAAGGGTGAGAAAG-3' & 221 \\
\hline Antisense & $5^{\prime}$-AGATCTTGGTAAAGCGAATG-3' & \\
\hline \multicolumn{3}{|l|}{ AdipoR1 } \\
\hline Sense & 5'-АСТGАСАСТTССССТGСAAG- $3^{\prime}$ & 500 \\
\hline Antisense & 5'-GTGGGGAGCAGTAGAAGGAA-3' & \\
\hline \multicolumn{3}{|c|}{ (2) } \\
\hline Sense & 5'-TGACTTCСТСТTGCATGGAC-3' & 440 \\
\hline Antisense & 5'-TGGCAGCCTTCAGGAACCCT-3' & \\
\hline \multicolumn{3}{|c|}{ 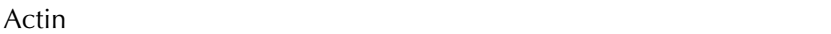 } \\
\hline Sense & 5'-ACGGAACCACAGTTTATCATC-3' & 188 \\
\hline Antisense & 5'-GTCCCAGTCTTCAACTATACC-3' & \\
\hline
\end{tabular}


PCR products were visualized in an agarose gel (1.5\%) and the DNAs were extracted from the agarose and sequenced in both the directions. PCR amplifications with RNA were performed in parallel as negative controls. RT-PCR consumables were purchased from Sigma, except Moloney murine leukaemia virus reverse transcriptase and RNase inhibitor (RNasin) from Promega. Experiment was realized on three different rats.

\section{Northern blot}

Total RNAs from tissue $(20 \mu \mathrm{g})$ were separated by denaturing formaldehyde electrophoresis, and then transferred to a nylon membrane and the membrane was hybridized as previously described (Tosca et al. 2005). AdipoR1 and AdipoR2 probes were obtained by RT-PCR using the primers indicated in Table 1 . They were then labelled using the Rediprime labelling kit (Amersham). After high stringency washings, membraneincorporated radioactivity was also quantified using a STORM apparatus. The integrity and the quantification of different transcripts were assessed using the human RNA 18 S probe as a control (Ambion, Woodward Austin, TX, USA). Experiment was performed on six rats from different groups (immature, PMSG, PMSG + hCG: $6,24$ or $48 \mathrm{~h})$.

\section{Western blot}

Lysates of granulosa cells $\left(2 \times 10^{5}\right.$ cells/well) or tissues were prepared on ice, as previously described by Tosca et al. (2005). Lysates were centrifuged at $13000 \mathrm{~g}$ for $20 \mathrm{~min}$ at $4{ }^{\circ} \mathrm{C}$, and the protein concentration in the supernatants was determined using a colorimetric assay (kit BC Assay, Uptima Interchim, Montluçon, France). Cell extracts were subjected to electrophoresis on $10 \%$ $(\mathrm{w} / \mathrm{v})$ SDS-PAGE under reducing conditions. The proteins were then electrotransferred onto nitrocellulose membranes. Membranes were incubated for $1 \mathrm{~h}$ at room temperature with Tris-buffered saline (TBS, $2 \mathrm{mM}$ Tris- $\mathrm{HCl}, \mathrm{pH} 8.0,15 \mathrm{mM} \mathrm{NaCl}, \mathrm{pH}$ 7.6), containing $5 \%$ nonfat dry milk powder (NFDMP) and $0.1 \%$ Tween20. Subsequently, they were incubated overnight at $4{ }^{\circ} \mathrm{C}$ with appropriate antibodies (final dilution 1:1000), in TBS containing $0.1 \%$ Tween-20 and 5\% NFDMP. After washing in TBS-Tween-20 $0.1 \%$, nitrocellulose membranes were incubated for $2 \mathrm{~h}$ at room temperature with a horseradish peroxidase-conjugated anti-rabbit or anti-mouse IgG (final dilution 1:10 000; Diagnostic Pasteur, Marnes-la-Coquette, France) in $0.1 \%$ TBS-Tween-20 and 5\% NFDMP. After washing in $0.1 \%$ TBS-Tween-20, the signal was detected by ECL (Enhanced chemiluminescence reagent; Amersham Pharmacia Biotech). The films were analysed and signals quantified with the software MacBas V2.52 (Fuji PhotoFilm, Inc., Valhalla, NY, USA). The results are expressed as the intensity signal in arbitrary units after normalization, allowed by the presence of vinculin, as an internal standard, and correspond to the average of three independent cultures. In each culture, each condition was tested in quadruplet.

\section{Thymidine incorporation into granulosa cells}

Granulosa cells $\left(2 \times 10^{5}\right.$ viable cells/500 $\left.\mu \mathrm{l}\right)$ were cultured in 24-well dishes in McCoy's 5A medium and $10 \%$ FBS during $48 \mathrm{~h}$ and were then serum starved for $24 \mathrm{~h}$, followed by the addition of $1 \mu \mathrm{Ci} / \mu \mathrm{l}$ of $\left[{ }^{3} \mathrm{H}\right]$ thymidine (Amersham Life Science) in the presence or absence of human recombinant adiponectin $(5 \mu \mathrm{g} / \mathrm{ml})$ and FSH $\left(10^{-8} \mathrm{M}\right)$ or IGF-I $\left(10^{-8} \mathrm{M}\right)$. After $24 \mathrm{~h}$ of culture, excess of thymidine was removed by washing twice with PBS, fixed with $50 \%$ cold trichloroacetic acid for 15 min and lysed by $0.5 \mathrm{~N} \mathrm{NaOH}$. The radioactivity was determined by scintillation fluid counting in a $\beta$-photomultiplier. Results are representative of at least three independent cultures. In each culture, each condition (IGF-I, FSH, adiponectin alone or combined with IGF-I or FSH) was analysed in triplicate.

\section{Immunohistochemistry}

Ovaries embedded in paraffin $(n=3$ rats in each condition) were serially sectioned at a thickness of $7 \mu \mathrm{m}$. Sections were deparaffinized, hydrated and microwaved for $5 \mathrm{~min}$ in antigen unmasking solution (Vector Laboratories, Inc., AbCys, Paris, France), and then allowed to cool to room temperature. After washing in a PBS bath for $5 \mathrm{~min}$, sections were immersed in peroxidase-blocking reagent for $10 \mathrm{~min}$ at room temperature to quench endogenous peroxidase activity (DAKO Cytomation, Dako, Ely, UK). After two washes in a PBS bath for 5 min, non-specific background was eliminated by blocking with $5 \%$ lamb serum in PBS for $20 \mathrm{~min}$, followed by incubation overnight at $4{ }^{\circ} \mathrm{C}$ with PBS containing rabbit primary antibody raised against either adiponectin (1:100, ACRP $30 \mathrm{~N}-20$, Santa Cruz Biotechnology), AdipoR1 or AdipoR2 (1:100, Phoenix Pharmaceuticals). Sections were washed twice for $5 \mathrm{~min}$ each time in a PBS bath and were incubated for $30 \mathrm{~min}$ at room temperature with a 'ready to use' labelled Polymer-HRPanti-rabbit (DakoCytomation Envision Plus HRP system, Dako, Ely, UK). The sections were then washed twice in PBS and the staining was revealed by incubation at room temperature with $3,3^{\prime}$-diaminobenzidine tetrahydrochloride (Liquid DAB + Substrate Chromogen System, DakoCytomation). Negative controls were involved replacing primary antibodies with rabbit IgG. As a positive control, we showed a strong expression of adiponectin and AdipoR1 in rat adipose tissue and skeletal muscle (Fig. 1 supplementary data). 


\section{ELISA and RIA}

Serum adiponectin concentrations were measured using a rat adiponectin ELISA kit (Phoenix Pharmaceuticals) and serum insulin levels were determined using a rat insulin ELISA kit (Mercodia AB, Uppsala, Sweden). The concentration of progesterone (P4) and oestradiol (E2) in the culture medium of granulosa cells was measured after $48 \mathrm{~h}$ of culture by a RIA protocol as previously described (Tosca et al. 2005). Results were expressed as the amount of steroids secreted for $48 \mathrm{~h}$ per $100 \mu \mathrm{g}$ protein. Results are means \pm s.D. of three cultures of granulosa cells. In each culture, each condition (IGF-I, $\mathrm{FSH}$, adiponectin alone or combined with IGF-I or FSH) was analysed in quadruplet.

\section{Statistical analysis}

All experimental data are presented as the mean \pm s.D. One-way ANOVA was used to test differences and if ANOVA revealed significant effects, the means were compared by Newman's test, with $P<0.05$ considered significant.

\section{Results}

\section{Adiponectin, AdipoR1 and AdipoR2 expression in rat ovary}

RT-PCR analysis with RNA from fresh granulosa cells $(\mathrm{G})$, dissected corpus luteum $(\mathrm{CL})$, adult rat ovary $(\mathrm{Ov})$ and oocyte (Oo) resulted in the amplification of three cDNAs corresponding to fragments of adiponectin (214 bp), AdipoR1 (540 bp) and AdipoR2 (720) (Fig. 1A). As expected, adiponectin, AdipoR1 and AdipoR2 are mainly expressed in adipose tissue (AT), muscle $(\mathrm{Mu})$ and liver (Li) respectively. Immunoblotting of protein extracts revealed one band corresponding to the adiponectin (about $30 \mathrm{kDa}$ ), the other band corresponding to AdipoR1 (about $41 \mathrm{kDa}$ ) and another corresponding to AdipoR2 (about $46 \mathrm{kDa}$ ) (Fig. 1B), showing that the adiponectin system is produced in rat ovary and more precisely in whole rat ovary, corpus luteum and oocyte. For the immunoblot experiments, we used reducing conditions and subjected the samples to heating for $5 \mathrm{~min}$. This can probably explain why we mainly observed the adiponectin monomer form (30 kDa). Similar results were observed for adiponectin in rat and human adipose tissue and placenta (Caminos et al. 2005). Isolation of fresh granulosa and T-I cells showed that adiponectin, AdipoR1 and AdipoR2 are present in fresh granulosa, but many less than that present in T-I cells (Fig. 1C). Similar results are obtained for cultured granulosa and T-I cells. Immunohistochemistry with ovarian sections from immature rats are treated with or without PMSG, and then hCG confirmed the immunoblot findings and demonstrated that adiponectin, AdipoR1 and AdipoR2 in T-I cells, oocyte and corpus luteum are more abundant than that in granulosa cells (Fig. 2). Thus, adiponectin receptors and their ligand are found in the different structures of the rat ovary, but mainly in T-I cells,

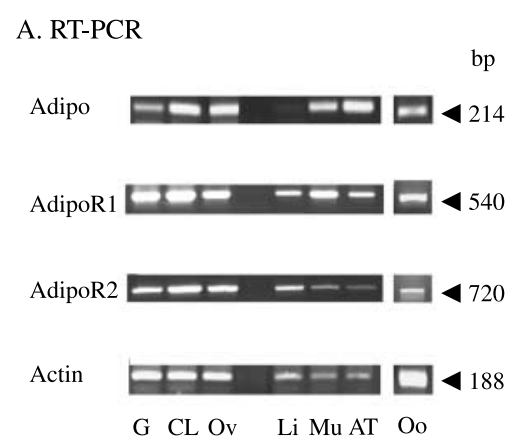

B. Western-blot

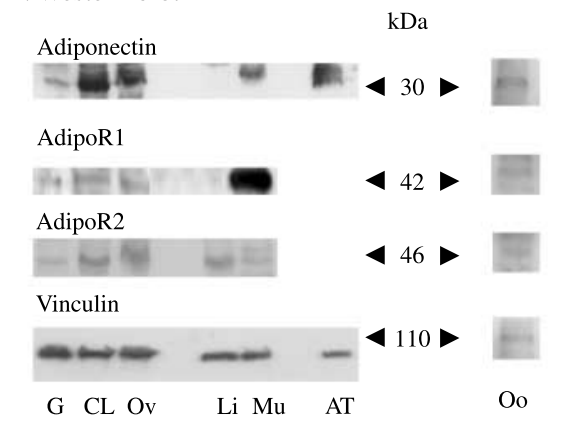

C. Western-blot (granulosa/theca-interstitial cells)

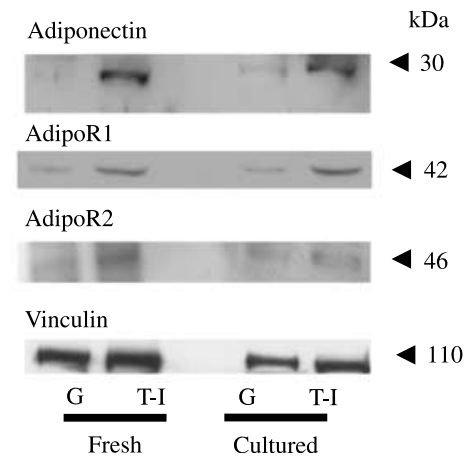

Figure 1 Detection of adiponectin, AdipoR1 and AdipoR2 transcripts and proteins in rat ovary. (A) RT-PCR analysis of adiponectin, AdipoR1 and AdipoR2 mRNAs. Total RNAs extracted from rat fresh granulosa cells (G), corpus luteum $(\mathrm{CL})$, whole ovary $(\mathrm{Ov})$ and oocyte (Oo) were subjected to RT-PCR, as described in materials and methods, using primers designed to amplify fragments of adiponectin (214 bp), AdipoR1 (540 bp) and AdipoR2 (720 bp). Rat adipose tissue, muscle and liver RNAs were used as a positive control for adiponectin, AdipoR1 and AdipoR2 respectively. (B and C) Detection of adiponectin (30 kDa), AdipoR1 (42 kDa) and AdipoR2 (46 kDa) proteins by immunoblotting. Protein extracts $(70 \mu \mathrm{g})$ from rat fresh granulosa cells $(\mathrm{G})$, corpus luteum $(\mathrm{CL})$, whole ovary $(\mathrm{Ov})$, liver ( $\mathrm{Li})$, muscle $(\mathrm{Mu})$ and adipose tissue (AT) and protein extracts from 40 rat oocytes were resolved by SDS-PAGE, transferred to a nitrocellulose membrane and incubated with specific antibodies against adiponectin, AdipoR1 or AdipoR2, and vinculin. In part (C), fresh or cultured granulosa $(\mathrm{G})$ and theca-interstitial T-I cells were submitted to western blot. 

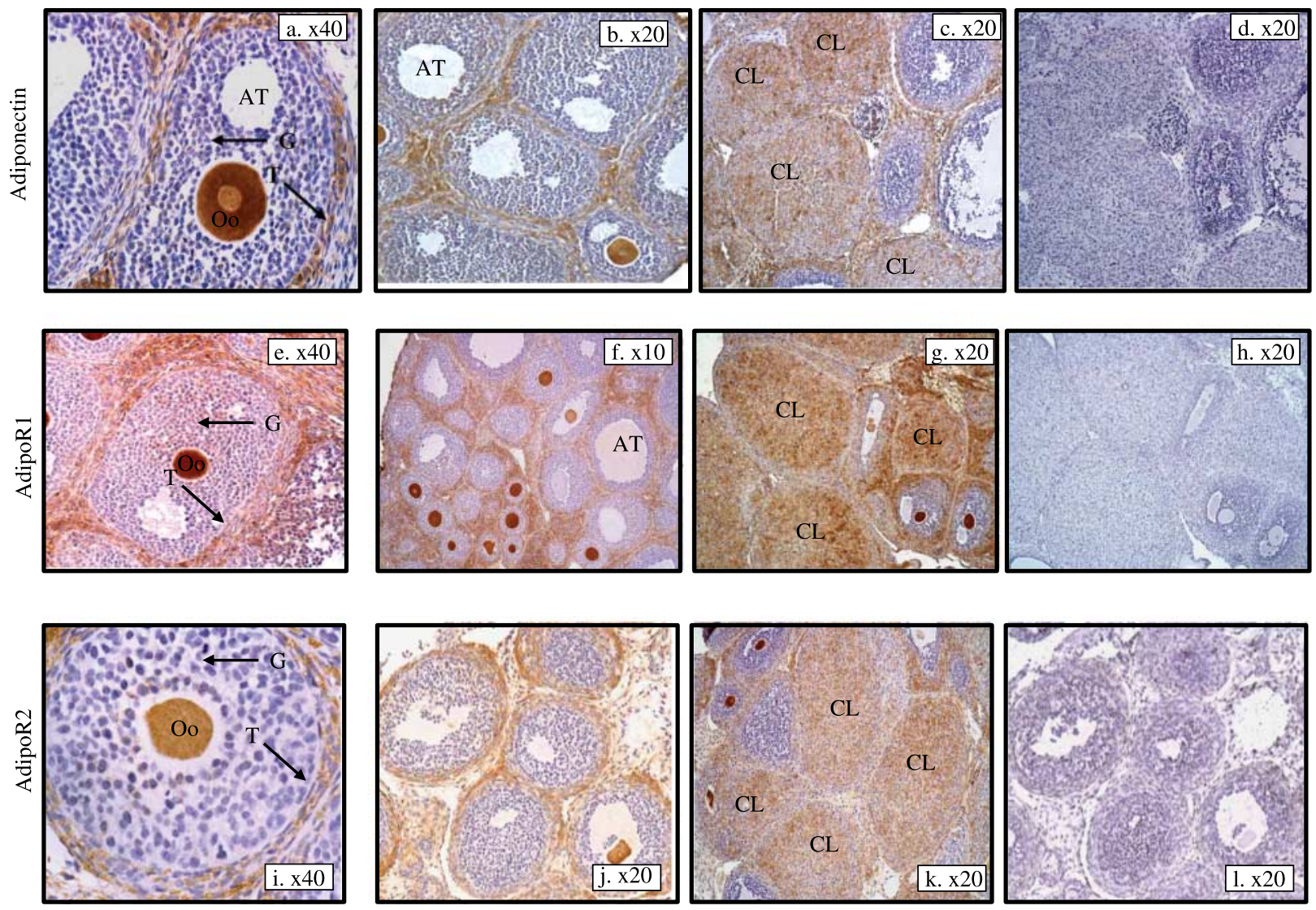

Figure 2 Localization of adiponectin, AdipoR1 and AdipoR2 in rat ovary by immunohistochemistry. Adiponectin, AdipoR1 and AdipoR2 are localized in large follicle in ovary from rat treated with PMSG for $24 \mathrm{~h}(\mathrm{a}, \mathrm{b}, \mathrm{e}, \mathrm{f}, \mathrm{i}$ and $\mathrm{j})$ and in corpus luteum in ovary from rat treated with PMSG for $24 \mathrm{~h}$ and then with hCG for $48 \mathrm{~h}$ (c, g, and k). Note that adiponectin, AdipoR1 and AdipoR2 are observed in theca cells (T), corpus luteum (CL) and oocyte (O) and less abundantly in granulosa cells (G). Negative controls included a section incubated with non-immune serum (d, h and I). AT, antrum.

\section{A. RT-PCR}

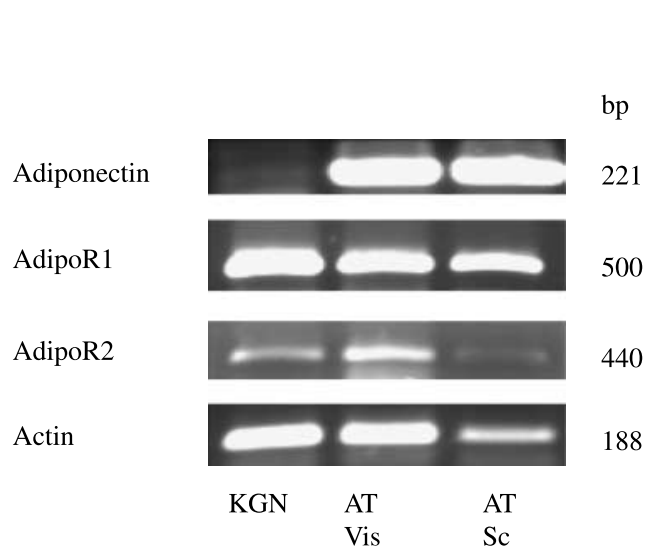

B. Westen-blot

\begin{tabular}{|c|c|c|c|}
\hline Adipone & ctin & & KL \\
\hline i & - & $=$ & 430 \\
\hline Vinculin & & & \\
\hline$F=$ & $=4$ & $=$ & 110 \\
\hline KGN & AT & AT & \\
\hline & Vis & $\mathrm{Sc}$ & \\
\hline AdipoR & & & \\
\hline 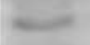 & & & 442 \\
\hline Vinculin & & & \\
\hline$\longrightarrow$ & & $\Rightarrow$ & 4110 \\
\hline $\mathrm{KGN}$ & & Muscle & \\
\hline AdipoR & & & \\
\hline 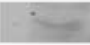 & 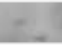 & 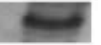 & 446 \\
\hline Vinculin & & & \\
\hline 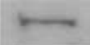 & & $=$ & $\ 110$ \\
\hline KGN & & Liver & \\
\hline
\end{tabular}

Figure 3 Detection of adiponectin, AdipoR1 and AdipoR2 transcripts and proteins in the KGN human granulosa cell line. (A) RT-PCR analysis of adiponectin, AdipoR1 and AdipoR2 mRNAs. Total RNA extracted from KGN cells was subjected to RT-PCR, as described in materials and methods, using primers designed to amplify fragments of adiponectin (221 bp), AdipoR1 (500 bp) and AdipoR2 (440 bp). Human subcutaneous (sc) and visceral adipose tissue RNAs were used as a positive control for adiponectin. (B) Detection of adiponectin (30 kDa), AdipoR1 $(42 \mathrm{kDa})$ and AdipoR2 (46 kDa) proteins by immunoblotting. Protein extracts $(70 \mu \mathrm{g})$ were resolved by SDS-PAGE, transferred to a nitrocellulose membrane and incubated with specific antibodies against adiponectin, AdipoR1 or AdipoR2 and vinculin. Human adipose tissue (subcutaneous (sc) and visceral (vs) from Ambion), rat muscle and liver lysates were used as a positive control for adiponectin, AdipoR1 and AdipoR2 respectively. 
oocyte and corpus luteum. We have also identified the adiponectin system (adiponectin, AdipoR1 and AdipoR2) in the KGN human granulosa cell line (Nishi et al. 2001). As shown in Fig. 3, adiponectin mRNA and protein were undetectable; AdipoR2 was weakly expressed, whereas AdipoR1 was clearly present in KGN cells (Fig. 3).

\section{Hormone-regulated expression of adiponectin, AdipoR1 and AdipoR2 1 and 2 in rat ovary}

To examine the hormonal regulation of the expression of adiponectin, AdipoR1 and AdipoR2 in rat ovaries, northern and western blot analyses were performed using ovaries isolated from the PMSG/hCG-treated rat. Results revealed that the adiponectin protein levels in immature rat ovaries increased in response to hCG treatment $(48 \mathrm{~h})$ after the PMSG injection $(24 \mathrm{~h})(P<$ 0.05, Fig. 4). As shown in Fig. 5A, quantification of northern blot showed that AdipoR1 mRNA was unchanged in rat immature ovaries in response to PMSG treatment $(24 \mathrm{~h})$, whereas it was increased by about 2.5-fold in response to hCG (24 or $48 \mathrm{~h}$ ) treatment after the PMSG treatment. Similar results were obtained by western blot at the protein level (Fig. 5B). Conversely, the levels of AdipoR2 mRNA (Fig. 5C) and protein (Fig. 5D) were unchanged in rat ovary in response to PMSG or hCG treatment when compared with immature ovaries.

As showed in Fig. 6A, plasma adiponectin levels as determined by ELISA or western blot were significantly

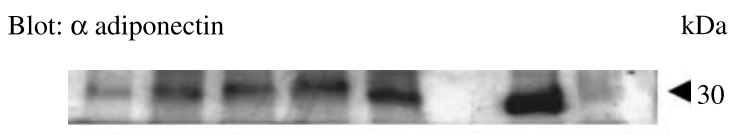

Blot: $\alpha$ vinculin

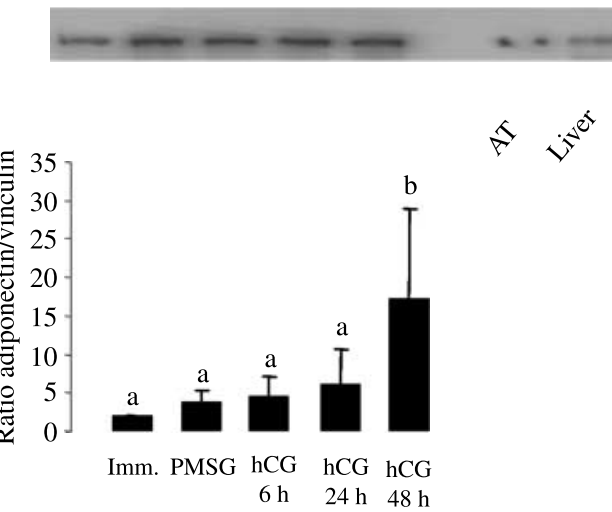

Figure 4 Western blot analysis of adiponectin protein level in rat ovary after the PMSG/hCG injection. All extracts contained equal amounts of proteins, as confirmed by reprobing membrane with an anti-vinculin antibody. Blots were quantitated and the ratio adiponectin/vinculin was represented. Values represent the means \pm s.D. ( $n=6$ rats per treatment). Different letters indicate a significant difference at $P<0.05$. Rat adipose tissue (AT) and liver lysates were used as positive and negative controls respectively. decreased in rats treated with PMSG/hCG (24 or $48 \mathrm{~h}$ ) when compared with untreated or treated with PMSG (24 h) immature rats. On the contrary, plasma insulin levels were significantly increased in response to PMSG/ hCG treatment $(24$ or $48 \mathrm{~h})$. Thus, PMSG $(24 \mathrm{~h}) / \mathrm{hCG}$ (48 h) treatment increased the adiponectin and AdipoR1 levels but not the AdipoR2 level in rat immature ovary, whereas it decreased plasma adiponectin levels.

\section{Effects of the human recombinant adiponectin on FSH- and IGF-I-stimulated progesterone and oestradiol production in rat granulosa cells}

Cells were cultured for $48 \mathrm{~h}$ in serum-free medium with $5 \mu \mathrm{g} / \mathrm{ml}$ human recombinant adiponectin in the presence and absence of IGF-I $\left(10^{-8} \mathrm{M}\right)$ or $\mathrm{FSH}$ $\left(10^{-8} \mathrm{M}\right)$. As shown in Fig. 7A and $\mathrm{B}$, adiponectin treatment increased IGF-I-induced progesterone and oestradiol secretion by 2 - and 1.5 -fold respectively, whereas it had no effect on the steroid productions in the presence or absence of FSH. This positive effect of human recombinant adiponectin on IGF-I-induced progesterone and oestradiol production was also observed at the dose of 1 and $10 \mu \mathrm{g} / \mathrm{ml}$ (Fig. 7C and D). We next determined whether this positive effect of adiponectin on progesterone and oestradiol production in the presence of IGF-I was a result of less of the two key enzymes of steroidogenesis (3 $\beta \mathrm{HSD}$ and p450scc) and/ or StAR, an important cholesterol carrier. As shown in Fig. 8A, human recombinant adiponectin $(5 \mu \mathrm{g} / \mathrm{ml})$ did not affect the amount of $3 \beta$ HSD, p450scc and StAR proteins in the presence or absence of FSH or IGF-I. Thus, recombinant adiponectin increased the progesterone and oestradiol production in response to IGF-I without affecting the protein level of $3 \beta \mathrm{HSD}$, p450scc and StAR in primary rat granulosa cells.

\section{Effects of human recombinant adiponectin on granulosa cell number}

We also investigated whether the dose of human recombinant adiponectin $(5 \mu \mathrm{g} / \mathrm{ml})$ used affected the number of granulosa cells in culture, either by induction of mitosis or altering the cell viability. [ $\left.{ }^{3} \mathrm{H}\right]$ Thymidine incorporation by granulosa cells treated with $5 \mu \mathrm{g} / \mathrm{ml}$ recombinant adiponectin was tested after $24 \mathrm{~h}$ in culture in the presence or absence of IGF-I or FSH. As expected, IGF-I and FSH significantly increased $\left[{ }^{3} \mathrm{H}\right]$ thymidine incorporation (Bley et al. 1992, Tosca et al. 2005; Fig. 8B). However, recombinant adiponectin had no effect on either the basal and IGF-I or FSH-stimulated state (Fig. 8B). As revealed by the staining with trypan blue, recombinant adiponectin treatment had no effect on cell viability in the presence or absence of $\mathrm{FSH}$ or IGF-I (data not shown). 
A
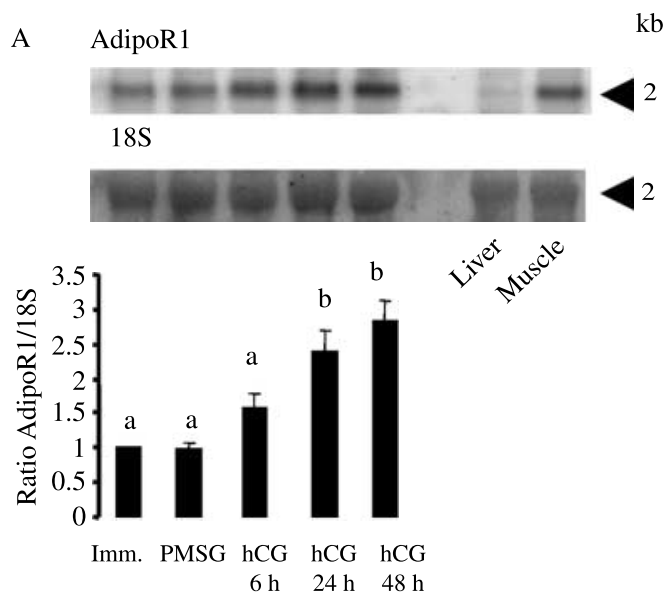

B Blot: $\alpha$ AdipoR1

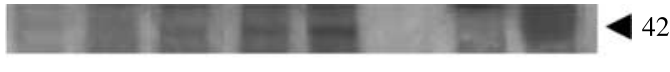

Blot: $\alpha$ vinculin
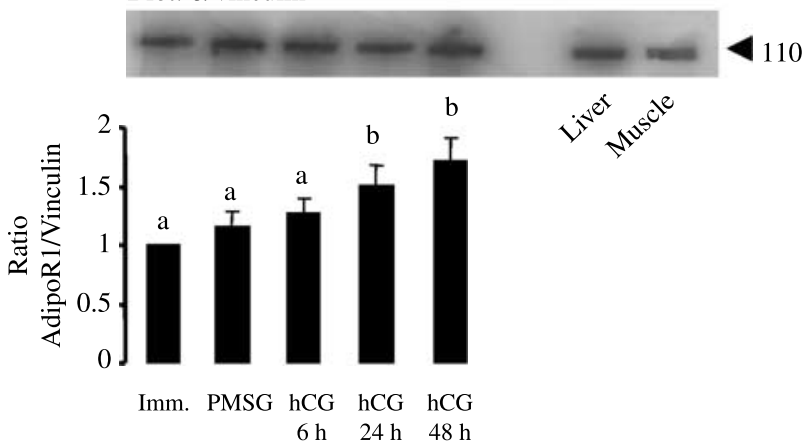

C AdipoR2
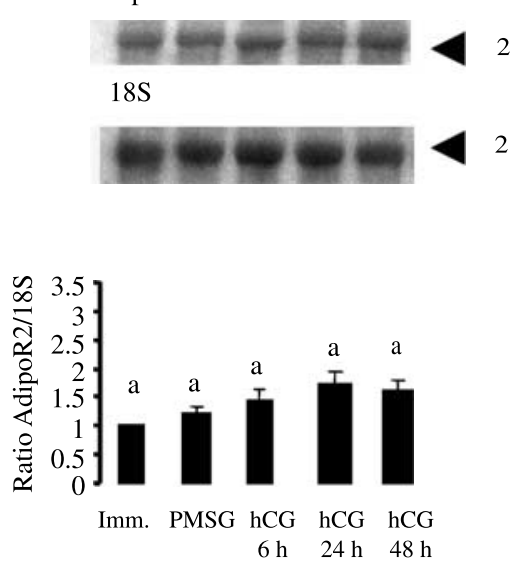

D Blot: $\alpha$ AdipoR2

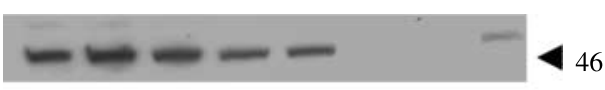

Blot: $\alpha$ vinculin
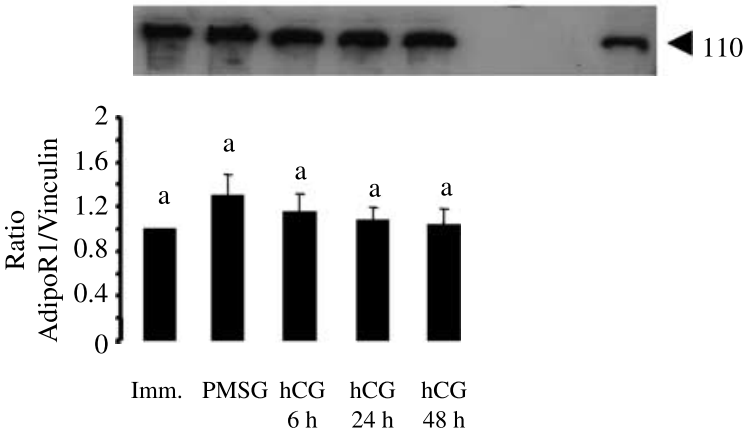

Figure 5 Northern blot ( $A$ and $C$ ) and western blot (B and D) analyses of AdipoR1 ( $A$ and B) and AdipoR2 (C and D) expression in rat ovary after the PMSG/hCG injection. For northern blot (A and C), the quantification of the radioactivity was realized using Storm apparatus and the ratios AdipoR1 and AdipoR2/18S are indicated. For western blot (C and D), all extracts contained equal amounts of proteins, as confirmed by reprobing membrane with an anti-tubulin antibody. Blots were quantitated and the ratios AdipoR1 and AdipoR2/vinculin were represented. Values represent the means \pm s.D. $(n=6$ rats per treatment). Different letters indicate a significant difference at $P<0.05$.

\section{Adiponectin activates various signalling pathways in rat granulosa cells}

Recombinant adiponectin is known to stimulate different signalling pathways including AMPK, MAPK and Akt in various cell types (Yamauchi et al. 2002, Wu et al. 2003, Ouchi et al. 2004, Luo et al. 2005). We investigated whether adiponectin receptor signalling via these pathways can be effective in primary rat granulosa cells. As shown in Fig. 9A, human recombinant adiponectin $(5 \mu \mathrm{g} / \mathrm{ml})$ increased rapidly (after $1 \mathrm{~min}$ of stimulation) but transiently the phosphorylation of MAPK (ERK1/2 and p38; Fig. 9A and B) and Akt (Fig. 9C). Conversely, phosphorylation of AMPK (Thr172) was increased more lately (after $30 \mathrm{~min}$ of stimulation) and was maintained after $1 \mathrm{~h}$ of stimulation in response to recombinant adiponectin (Fig. 9D). Thus, human recombinant adiponectin is able to activate several signalling pathways with different time courses in rat granulosa cells.
To investigate the molecular mechanism involved in the positive effects of adiponectin on the IGF-I-induced progesterone and oestradiol secretion, we determined the level of IGF-IR- $\beta$ subunit tyrosine phosphorylation in response to recombinant human adiponectin $(5 \mu \mathrm{g} / \mathrm{ml}$, $60 \mathrm{~min})$ in the presence or absence of IGF-I $\left(10^{-8} \mathrm{M}\right.$, $2 \mathrm{~min}$ ). As shown in Fig. 10A, recombinant human adiponectin greatly increased the IGF-I-induced tyrosine phosphorylation of IGF-IR- $\beta$ subunit without affecting the amount of IGF-IR (Fig. 10A). Moreover, we have observed similar results for the phosphorylation of MAPK ERK1/2 (Fig. 10B).

\section{Discussion}

In the present work, we showed for the first time that AdipoR1 and AdipoR2, were present in rat ovary, and more precisely in T-I cells, corpus luteum and oocyte and less abundantly in granulosa cells. In vivo, hCG 
A

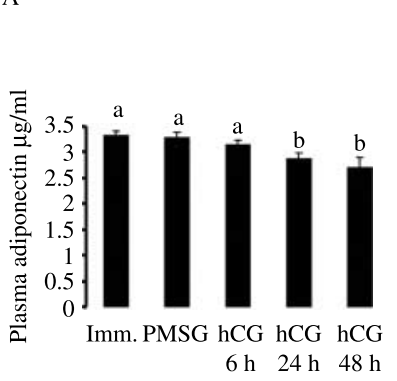

B

$\mathrm{kDa}$ Blot: $\alpha$ adiponectin

42

Ponceau staining

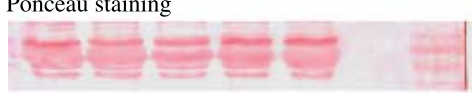

AT

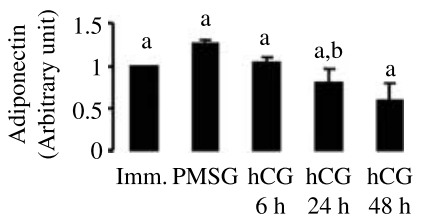

Figure 6 Adiponectin plasma levels (A) and adiponectin protein level in plasma determined by immunoblot (B) after the PMSG/hCG injection. Adiponectin plasma levels were analysed by ELISA. For western blot (B), all serum samples contained equal amounts of proteins, as confirmed by staining the nitrocellulose membrane with Ponceau. Blots were quantitated and the arbitrary values were represented. Values represent the means \pm s.D. ( $n=6$ rats per treatment). Different letters indicate a significant difference at $P<0.05$. Rat adipose tissue lysates were used as a positive control for adiponectin. (C) Insulin plasma levels determined by ELISA assay after the PMSG/hCG injection. Values represent the means \pm s.D. ( $n=6$ rats per treatment). Different letters indicate a significant difference at $P<0.05$. treatment $(48 \mathrm{~h})$ after the PMSG treatment (24 h) increased the levels of adiponectin protein and those of AdipoR1 (mRNA and protein) in immature rat ovaries. In these latter conditions, the levels of AdipoR2 (mRNA and protein) were unchanged and the plasma adiponectin concentration as determined by western blot and ELISA was reduced. In vitro in primary rat granulosa cells, human adiponectin recombinant $(5 \mu \mathrm{g} / \mathrm{ml})$ increased rapidly but transiently the phosphorylation of MAPK (ERK1/2 and p38) and Akt, whereas it induced more lately the phosphorylation of AMPK. In these cells, human adiponectin recombinant also increased the production of both progesterone and oestradiol in response to IGF-I $\left(10^{-8} \mathrm{M}, 48 \mathrm{~h}\right)$, whereas it had no effect in the presence or absence of FSH $\left(10^{-8} \mathrm{M}, 48 \mathrm{~h}\right)$.

We have identified adiponectin in rat ovary by using several approaches to assess the mRNA and protein. Adiponectin has already been found in the ovaries of different species, including chicken (Maddineni et al. 2005) and porcine (Lord et al. 2005, Ledoux et al. 2006).
A

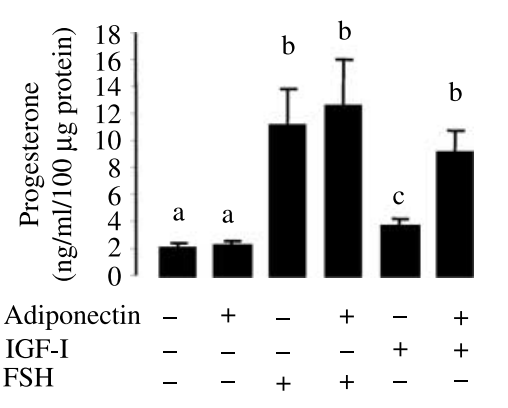

C

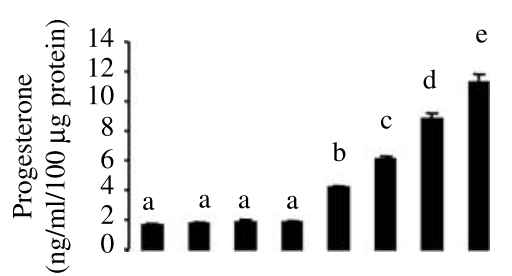

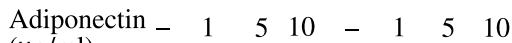
$(\mu \mathrm{g} / \mathrm{ml})$

IGF-I
B

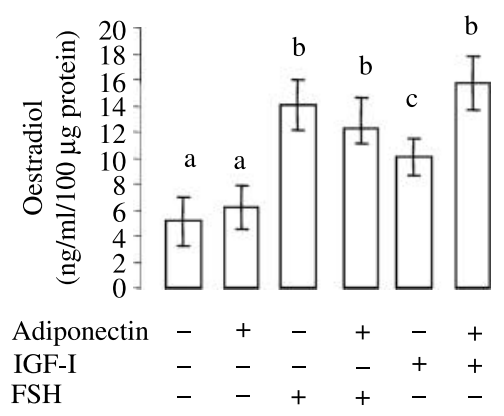

$\mathrm{D}$

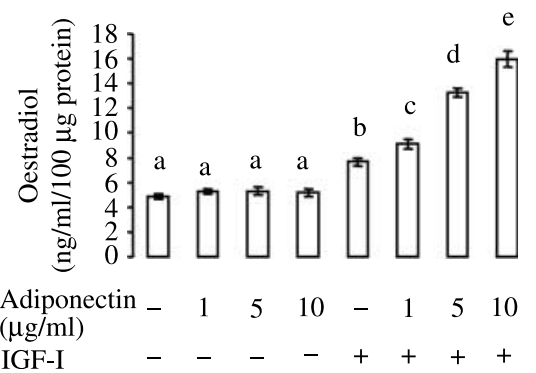

Figure 7 Effect of human adiponectin recombinant on the progesterone ( $\mathrm{A}$ and $\mathrm{C}$ ) and oestradiol $(B$ and $D)$ secretion in rat granulosa cells. Granulosa cells from immature rats were cultured for $48 \mathrm{~h}$ in serum-free medium in the presence or absence of IGF-I $\left(10^{-8} \mathrm{M}\right)$, FSH $\left(10^{-8} \mathrm{M}\right)$ and human adiponectin recombinant $(1,5$ or $10 \mu \mathrm{g} / \mathrm{ml})$. The culture medium was then collected and analysed for progesterone and oestradiol contents by RIA. Results are the means \pm s.D. of three groups of granulosa cells. Different letters indicate a significant difference at $P<0.05$. 
A

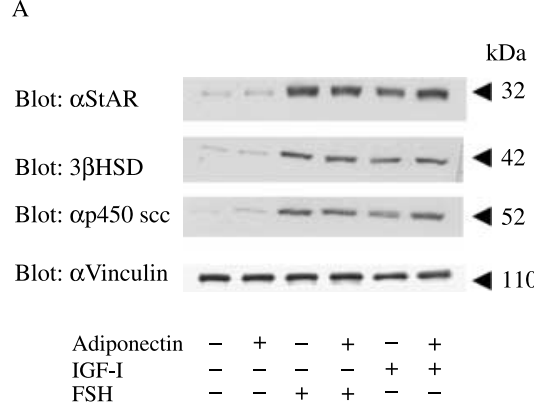

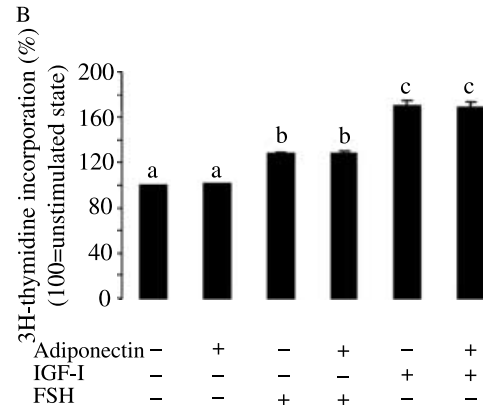

Figure 8 Effect of human recombinant adiponectin on the level of 3 $\beta$-HSD, p450scc and StAR protein (A) and on the cell number (B) in rat granulosa cells. (A) Protein extracts from rat granulosa cells cultured for $48 \mathrm{~h}$ in the presence or absence of IGF-I, FSH and human adiponectin recombinant were subjected to SDS-PAGE, as described in materials and methods. The membranes were incubated with antibodies raised against $3 \beta$-HSD, p450scc and StAR. Equal protein loading was verified by reprobing membrane with an anti-vinculin antibody. Results are representative of at least three independent experiments. (B) Effect of human recombinant adiponectin on the proliferation of rat granulosa cells. Thymidine incorporation was determined in rat granulosa cells cultured for $24 \mathrm{~h}$ in serum-free medium in the presence or absence of IGF-I or FSH, as described in materials and methods. Results are expressed as the percentage of thymidine incorporated when compared with the unstimulated state. Results are representative of at least three independent experiments. The results are expressed as means \pm s.D.

In porcine ovaries, adiponectin is present in follicular fluid (Ledoux et al. 2006). However, the cellular localization of adiponectin in ovary has never been described in mammals. Here, we found by immunohistochemistry and western blot that the amount of adiponectin protein was weakly expressed in rat granulosa cells when compared with T-I cells. These results are in good agreement with data that we have recently obtained in chicken ovarian cells. Indeed, in this latter species, we have shown that the level of adiponectin mRNA was about 10-30-fold higher in theca than in granulosa cells (Chabrolle et al. in press). Furthermore, we have shown that adiponectin (mRNA or protein) was undetectable in the KGN granulosa cell line. These data suggest that granulosa cells are not the main ovarian cells that produce adiponectin. In rat ovary, we have also identified the two adiponectin receptors AdipoR1 and AdipoR2. Like their ligand, these receptors are strongly expressed in T-I cells. However, we have shown that AdipoR2 and mainly AdipoR1 (mRNA and protein) were present in rat granulosa cells and the KGN human granulosa cells, suggesting that adiponectin from
A

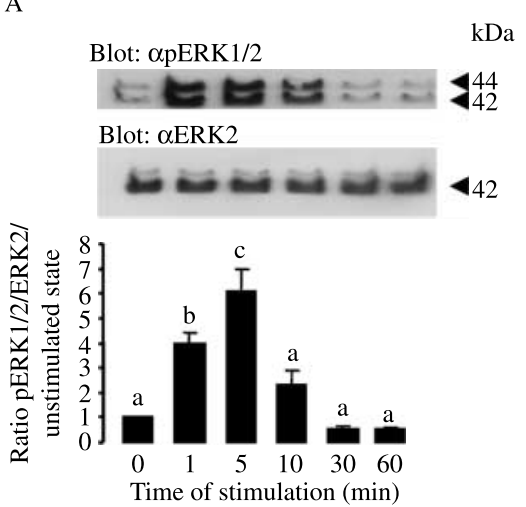

C

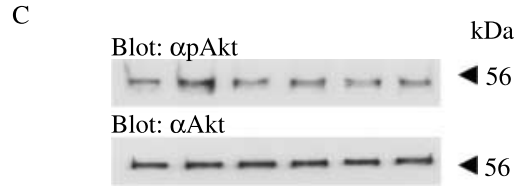

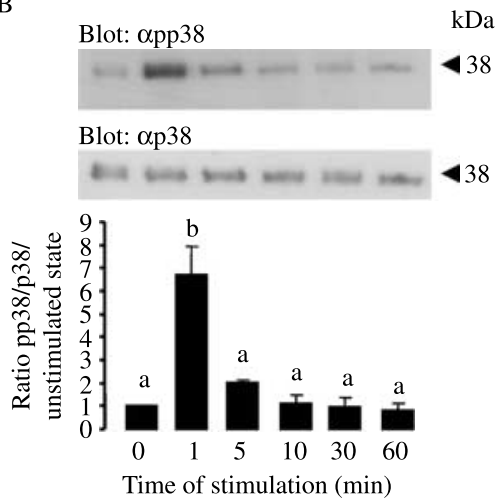

D

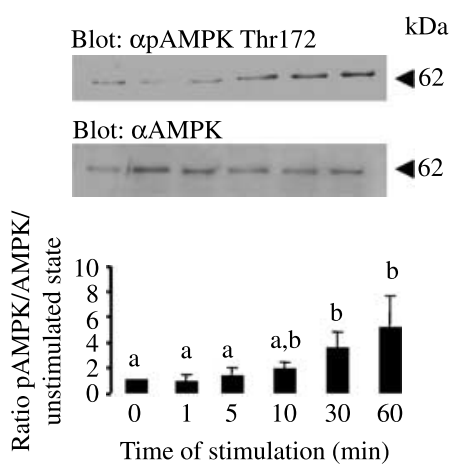

Figure 9 Human adiponectin recombinant activates MAPK ERK1/2, MAPK p38, AKT and AMPK signalling pathways in rat granulosa cells. Rat primary granulosa cells were serumstarved overnight and then stimulated with human adiponectin recombinant $(5 \mu \mathrm{g} / \mathrm{ml})$ for indicated times. To determine the level of MAPK ERK1/2, p38, Akt and AMPK Thr172 phosphorylation, all the blots were stripped and reprobed with antibodies against ERK2, p38, Akt and AMPK proteins respectively. Then, the ratio of phosphorylation/total protein was determined and plotted as the ratio of stimulation when compared with the unstimulated state. Values represent means \pm s.D. from three independent experiments. 


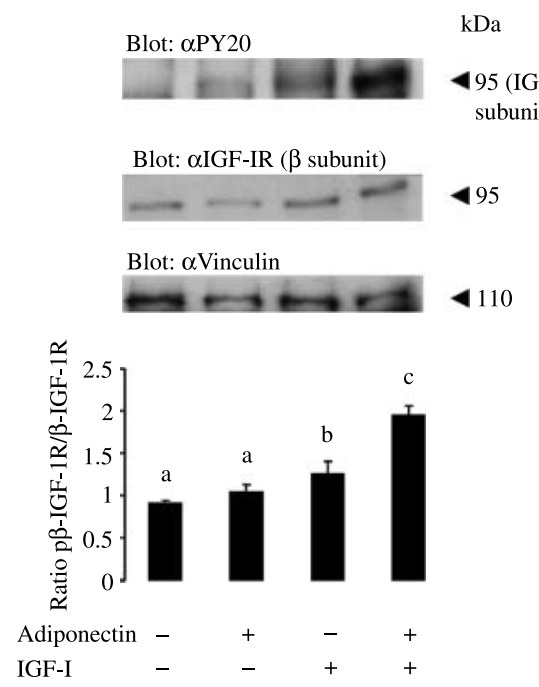

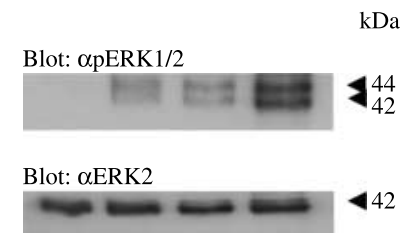

\begin{abstract}
Figure 10 Human adiponectin recombinant increases IGF-IR subunit tyrosine phosphorylation and MAPK ERK1/2 phosphorylation in rat granulosa cells. Rat primary granulosa cells were serum-starved overnight and then stimulated with human adiponectin recombinant $(5 \mu \mathrm{g} / \mathrm{ml})$ for $1 \mathrm{~h}$ in the absence or presence of IGF-I $\left(10^{-8} \mathrm{M}\right.$, 2 min). To determine the level of tyrosine phosphorylation of IGF-IR- $\beta$ subunit and MAPK ERK1/2 phosphorylation, all the blots were stripped and reprobed with antibodies against ERK2 and IGF-IR- $\beta$ subunit respectively. Then, the ratio of phosphorylation/total protein was determined. Values represent means \pm s.D. from two independent experiments.
\end{abstract}

T-I cells or serum could mediate some biological effects in these cells. In rat granulosa and theca cells, we found by immunohistochemistry that there was no variation in the levels of AdipoR1 and AdipoR2 during follicular development (data not shown). In the porcine ovary, AdipoR1 and AdipoR2 are also present in granulosa cells of follicles (Ledoux et al. 2006). In porcine granulosa cells, the levels of AdipoR1 and AdipoR2 transcripts are similar in small, medium and large follicles (Ledoux et al. 2006). Interestingly, we have identified adiponectin, AdipoR1 and AdipoR2 in rat oocyte and corpus luteum. Adiponectin possesses insulin-sensitizing actions (Kadowaki \& Yamauchi 2005). Insulin receptors or corresponding mRNAs have been identified in human or swine ovary in stromal, granulosa and theca cells but also in growing follicles (Poretsky et al. 1985, el-Roeiy et al. 1993, Samoto et al. 1993, Quesnel 1999). A role for insulin has been described in porcine oocyte maturation (Tsafriri \& Channing 1975). Furthermore, it is well known that adiponectin activates AMPK in various cell types (Huypens et al. 2005, Yoon et al. 2006, Chabrolle et al. in press). This kinase increases glucose uptake by increasing the rate of glucose transport in some cells (Fujii et al. 2006, Ju et al. 2007) and also plays an important role in the mouse oocyte maturation (Downs et al. 2002, Chen et al. 2006). Thus, adiponectin could improve the oocyte maturation in response to insulin through an activation of AMPK. Adiponectin also activates and participates in the actions of PPARs (Yamauchi et al. 2001, Nawrocki et al. 2006). PPARs are a family of nuclear hormone receptors involved in various processes that could influence ovarian function (Komar et al. 2001). For example, PPAR- $\gamma$ is primarily localized to granulosa cells and has negative effects on the luteinization of these cells (Komar et al. 2001). In contrast, PPAR- $\alpha$ and $-\delta$ are primarily located in theca and stromal cells and could play a role in basal ovarian function (Komar et al. 2001). Thus, in theca or granulosa cells, adiponectin could affect ovarian function through a PPAR-dependent mechanism. In a recent work, Ledoux et al. showed that recombinant adiponectin was able to induce the expression of cyclooxygenase-2 (COX2), prostaglandin E synthase (PGES) and vascular epidermal growth factor (VEGF) genes in porcine granulosa cells (Ledoux et al. 2006). VEGF is known to be necessary for the vascularization of the developing corpus luteum in rat ovary (Sakurai et al. 2004), and COX2 and PGEs are key rate-limiting enzymes in prostaglandin biosynthesis (Murakami et al. 2000). Here, we observed a strong expression of adiponectin in the corpus luteum, suggesting that it could be associated with rat luteal growth and development.

Here, we have explored the expression level (mRNA and protein) of adiponectin, AdipoR1 and AdipoR2 in rat immature ovary in response to PMSG and hCG treatments. We have demonstrated that the levels of adiponectin and those of AdipoR1 in rat ovary increased significantly in response to hCG treatment (24 or/and $48 \mathrm{~h}$ ), whereas the plasma adiponectin levels concomitantly decreased $(P<0.05)$. Furthermore, in the same conditions, the amount of AdipoR2 (mRNA and protein) was unchanged. This weak decrease (about 17\%, $P<0.05$ ) in the rat plasma adiponectin levels in response to hCG treatment is contrary to some data obtained in women during hCG treatment for in vitro fertilization. In this latter report, $\mathrm{FSH}$ treatment decreased serum adiponectin in women, whereas hCG treatment increased it (Liu et al. 2006). hCG is a LH-like hormone, whereas PMSG is known to mimic the FSH effects. In our study, we did not observe any effect of PMSG treatment on adiponectin treatment in rat. Liu et al. (2006) suggest that high oestradiol levels could exert negative effect 
on adiponectin production. However, the effects of the sexual steroids on the adiponectin level are not clear (Combs et al. 2003). The hCG injection after the PMSG treatment is known to induce ovulation and luteinization. This increase in the adiponectin and AdipoR1 in immature rats could be due to the high proportion of corpus luteum in the rat ovary in response to hCG treatment. However, with this latter hypothesis, the absence of variation in the AdipoR2 mRNA or protein level remains unexplained. In our study, hCG treatment decreased significantly plasma adiponectin level. This result could be related to the increase in the plasma insulin levels that could be a consequence to a reduction in the insulin sensitivity. A number of clinical studies revealed a strong link between wholebody insulin sensitivity and circulating adiponectin levels (Pajvani \& Scherer 2003).

In the present study, we have demonstrated that human recombinant adiponectin had no effect on the production of progesterone and oestradiol in the presence or absence of $\mathrm{FSH}\left(10^{-8} \mathrm{M}\right)$ in rat granulosa cells. However, it significantly increased the IGF-I effects on the production of these steroids. These effects were observed without modifications in the protein levels of StAR, $3 \beta$ HSD and p450scc, suggesting that human adiponectin recombinant could enhance the activity of enzymes and/or the substrate availability/mobilization or other factors involved in the steroidogenesis in response to IGF-I. We have also shown that human recombinant adiponectin $(5 \mu \mathrm{g} / \mathrm{ml})$ for $1 \mathrm{~h}$ was able to increase IGFIR- $\beta$ subunit tyrosine phosphorylation and MAPK ERK1/2 phosphorylation. Since the MAPK ERK1/2 signalling pathway is involved in the progesterone production in rat granulosa cells (Moore et al. 2001, Tosca et al. 2005), we can hypothesize that human recombinant adiponectin increases the IGF-I effects on the progesterone production through the MAPK ERK $1 / 2$ pathway. This increase in IGF-I effects on the production of steroids in response to adiponectin is not surprising since adiponectin is known to increase insulin sensitivity in different cell types. For example, in muscle cells, adiponectin increases tyrosine phosphorylation of insulin receptor and IRS-1 and also phosphorylation of Akt in response to insulin (Yamauchi et al. 2001).

In conclusion, we have demonstrated that the adiponectin system (adiponectin, AdipoR1 and AdipoR2) was strongly expressed in rat theca cells, corpus luteum and oocyte. AdipoR2 and mainly AdipoR1 were also present in rat granulosa cells and human granulosa KGN cells. Further experiments are necessary to determine the role of this adiponectin system in theca cells and oocyte. In particular, the role of adiponectin in the androgens production in theca cells needs to be investigated. Indeed, in human ovary, this adiponectin system could be involved in the PCOS syndrome.

\section{Acknowledgements}

The authors thank M Peloille for the sequencing, C Cahier and J C Braguer for the animal care, M Plat for her help in collecting rat oocytes and $\mathrm{H}$ Nawata for the KGN cell line. Lucie Tosca is a PhD student supported by the Région Centre. The authors declare that there is no conflict of interest that would prejudice the impartiality of this scientific work.

\section{References}

Ardawi MS \& Rouzi AA 2005 Plasma adiponectin and insulin resistance in women with polycystic ovary syndrome. Fertility and Sterility 84 1708-1716.

Berg AH, Combs TP, Du X, Brownlee M \& Scherer PE 2001 The adipocyte-secreted protein Acrp30 enhances hepatic insulin action. Nature Medicine 7 947-953.

Bley MA, Simon JC, Estevez AG, de Asua LJ \& Baranao JL 1992 Effect of follicle-stimulating hormone on insulin-like growth factor-I-stimulated rat granulosa cell deoxyribonucleic acid synthesis. Endocrinology 131 1223-1229.

Caminos JE, Nogueiras R, Gallego R, Bravo S, Tovar S, GarciaCaballero T, Casanueva FF \& Dieguez C 2005 Expression and regulation of adiponectin and receptor in human and rat placenta. Journal of Clinical Endocrinology and Metabolism 90 4276-4286.

Chabrolle C, Tosca L, Crochet S, Tesseraud S, Dupont J 2006 Expression of AdipoR1 and AdipoR2 in chicken ovary: potential role in ovarian steroidogenesis. Domestic Animal Endocrinology [in press].

Charreau B, Tesson L, Soulillou JP, Pourcel C \& Anegon I 1996 Transgenesis in rats: technical aspects and models. Transgenic Research 5 223-234.

Chen J, Hudson E, Chi MM, Chang AS, Moley KH, Hardie DG \& Downs SM 2006 AMPK regulation of mouse oocyte meiotic resumption in vitro. Developmental Biology 291 227-238.

Combs TP, Berg AH, Obici S, Scherer PE \& Rossetti L 2001 Endogenous glucose production is inhibited by the adipose-derived protein Acrp30. Journal of Clinical Investigation 108 1875-1881.

Combs TP, Berg AH, Rajala MW, Klebanov S, Iyengar P, JimenezChillaron JC, Patti ME, Klein SL, Weinstein RS \& Scherer PE 2003 Sexual differentiation, pregnancy, calorie restriction, and aging affect the adipocyte-specific secretory protein adiponectin. Diabetes $\mathbf{5 2}$ 268-276.

Downs SM, Hudson ER \& Hardie DG 2002 A potential role of AMPactivated protein kinase in meiotic induction in mouse oocytes. Developmental Biology 245 200-212.

Duleba AJ, Spaczynski RZ, Olive DL \& Behrman HR 1997 Effects of insulin and insulin-like growth factors on proliferation of rat ovarian theca-interstitial cells. Biology of Reproduction $\mathbf{5 6}$ 891-897.

el-Roeiy A, Chen X, Roberts VJ, LeRoith D, Roberts CT Jr \& Yen SS 1993 Expression of insulin-like growth factor-I (IGF-I) and IGF-II and the IGF-I, IGF-II, and insulin receptor genes and localization of the gene products in the human ovary. Journal of Clinical Endocrinology and Metabolism 77 1411-1418.

Fruebis J, Tsao TS, Javorschi S, Ebbets-Reed D, Erickson MR, Yen FT, Bihain BE \& Lodish HF 2001 Proteolytic cleavage product of 30-kDa adipocyte complement-related protein increases fatty acid oxidation in muscle and causes weight loss in mice. PNAS 98 2005-2010.

Fujii N, Jessen N \& Goodyear LJ 2006 AMP-activated protein kinase and the regulation of glucose transport. American Journal of Physiology, Endocrinology and Metabolism 291 E867-E877.

Huypens P, Moens K, Heimberg H, Ling Z, Pipeleers D \& Van de Casteele M 2005 Adiponectin-mediated stimulation of AMPactivated protein kinase (AMPK) in pancreatic beta cells. Life Sciences 77 1273-1282. 
Ju JS, Gitcho MA, Casmaer CA, Patil PB,, Han DG, Spencer SA \& Fisher JS 2007 Potentiation of insulin-stimulated glucose transport by the AMP-activated protein kinase. American Journal of Physiology and Cellular Physiology 292 C564-C572.

Kadowaki T \& Yamauchi T 2005 Adiponectin and adiponectin receptors. Endocrine Reviews 26 439-451.

Komar CM, Braissant O, Wahli W \& Curry TE Jr 2001 Expression and localization of PPARs in the rat ovary during follicular development and the periovulatory period. Endocrinology 142 4831-4838.

Lanfranco F, Zitzmann M, Simoni M \& Nieschlag E 2004 Serum adiponectin levels in hypogonadal males: influence of testosterone replacement therapy. Clinical Endocrinology (Oxford) 60 500-507.

Ledoux S, Campos DB, Lopes FL, Dobias-Goff $M$, Palin MF \& Murphy BD 2006 Adiponectin induces peri-ovulatory changes in ovarian follicular cells. Endocrinology 147 5178-5186.

Liu YH, Tsai EM, Chen YL, Chen HS, Chen YC, Wu LC, Lee CH, Jong SB \& Chan TF 2006 Serum adiponectin levels increase after human chorionic gonadotropin treatment during in vitro fertilization. Gynecologic and Obstetric Investigation 62 61-65.

Lord E, Ledoux S, Murphy BD, Beaudry D \& Palin MF 2005 Expression of adiponectin and its receptors in swine. Journal of Animal Science 83 565-578.

Luo XH, Guo LJ, Yuan LQ, Xie H, Zhou HD, Wu XP \& Liao EY 2005 Adiponectin stimulates human osteoblasts proliferation and differentiation via the MAPK signaling pathway. Experimental Cell Research 309 99-109.

Maddineni S, Metzger S, Ocon O, Hendricks G 3rd \& Ramachandran R 2005 Adiponectin gene is expressed in multiple tissues in the chicken: food deprivation influences adiponectin messenger ribonucleic acid expression. Endocrinology 146 4250-4256.

Maeda K, Okubo K, Shimomura I, Funahashi T, Matsuzawa Y \& Matsubara K 1996 cDNA cloning and expression of a novel adipose specific collagen-like factor, apM1 (AdiPose Most abundant Gene transcript 1). Biochemical and Biophysical Research Communications 221 286-289.

Moore RK, Otsuka F \& Shimasaki S 2001 Role of ERK1/2 in the differential synthesis of progesterone and estradiol by granulosa cells. Biochemical and Biophysical Research Communications 289 796-800

Murakami M, Naraba H, Tanioka T, Semmyo N, Nakatani Y, Kojima F, Ikeda T, Fueki M, Ueno A, Oh S \& Kudo I 2000 Regulation of prostaglandin E2 biosynthesis by inducible membrane-associated prostaglandin E2 synthase that acts in concert with cyclooxygenase-2. Journal of Biological Chemistry 275 32783-32792.

Nawrocki AR, Rajala MW, Tomas E, Pajvani UB, Saha AK, Trumbauer ME, Pang Z, Chen AS, Ruderman NB, Chen H, Rossetti L \& Scherer PE 2006 Mice lacking adiponectin show decreased hepatic insulin sensitivity and reduced responsiveness to peroxisome proliferator-activated receptor gamma agonists. Journal of Biological Chemistry 281 2654-2660.

Ng SC 1986 Laboratory manual for IVF. Department of Obstretrics and Genecology. Singapore: National University of Singapore.

Nishi Y, Yanase T, Mu Y, Oba K, Ichino I, Saito M, Nomura M, Mukasa C, Okabe T, Goto K et al. 2001 Establishment and characterization of a steroidogenic human granulosa-like tumor cell line, KGN, that expresses functional follicle-stimulating hormone receptor. Endocrinology 142 437-445.

Ouchi N, Kihara S, Arita Y, Nishida M, Matsuyama A, Okamoto Y, Ishigami M, Kuriyama H, Kishida K, Nishizawa H et al. 2001 Adipocyte-derived plasma protein, adiponectin, suppresses lipid accumulation and class A scavenger receptor expression in human monocyte-derived macrophages. Circulation 103 1057-1063.

Ouchi N, Kobayashi H, Kihara S, Kumada M, Sato K, Inoue T, Funahashi T \& Walsh K 2004 Adiponectin stimulates angiogenesis by promoting cross-talk between AMP-activated protein kinase and Akt signaling in endothelial cells. Journal of Biological Chemistry 279 1304-1309.
Pajvani UB \& Scherer PE 2003 Adiponectin: systemic contributor to insulin sensitivity. Current Diabetes Reports 3 207-213.

Poretsky L, Grigorescu F, Seibel M, Moses AC \& Flier JS 1985 Distribution and characterization of insulin and insulin-like growth factor I receptors in normal human ovary. Journal of Clinical Endocrinology and Metabolism 61 728-734.

Quesnel H 1999 Localization of binding sites for IGF-I, insulin and GH in the sow ovary. Journal of Endocrinology 163 363-372.

Ramachandran R, Ocon-Grove OM \& Metzger SL 2006 Molecular cloning and tissue expression of chicken AdipoR1 and AdipoR2 complementary deoxyribonucleic acids. Domestic Animal Endocrinology [in press].

Sakurai T, Tamura K \& Kogo H 2004 Vascular endothelial growth factor increases messenger RNAs encoding cyclooxygenase II and membrane-associated prostaglandin $\mathrm{E}$ synthase in rat luteal cells. Journal of Endocrinology 183 527-533.

Samoto T, Maruo T, Ladines-Llave CA, Matsuo H, Deguchi J, Barnea ER \& Mochizuki M 1993 Insulin receptor expression in follicular and stromal compartments of the human ovary over the course of follicular growth, regression and atresia. Endocrine Journal 40 $715-726$.

Scherer PE, Williams S, Fogliano M, Baldini G \& Lodish HF 1995 A novel serum protein similar to $\mathrm{C} 1 \mathrm{q}$, produced exclusively in adipocytes. Journal of Biological Chemistry 270 26746-26749.

The Rotterdam ESHRE/ASRM-Sponsored PCOS consensus workshop group 2004 Revised 2003 consensus on diagnostic criteria and longterm health risks related to polycystic ovary syndrome (PCOS). Human Reproduction 19 41-47.

Tosca L, Froment P, Solnais P, Ferre P, Foufelle F \& Dupont J 2005 Adenosine $5^{\prime}$-monophosphate-activated protein kinase regulates progesterone secretion in rat granulosa cells. Endocrinology $\mathbf{1 4 6}$ $4500-4513$

Tsafriri A \& Channing CP 1975 Influence of follicular maturation and culture conditions on the meiosis of pig oocytes in vitro. Journal of Reproduction and Fertility 43 149-152.

Tsuchida A, Yamauchi T, Ito Y, Hada Y, Maki T, Takekawa S, Kamon J, Kobayashi M, Suzuki R, Hara K et al. 2004 Insulin/Foxo1 pathway regulates expression levels of adiponectin receptors and adiponectin sensitivity. Journal of Biological Chemistry 279 30817-30822.

Wu X, Motoshima H, Mahadev K, Stalker TJ, Scalia R \& Goldstein BJ 2003 Involvement of AMP-activated protein kinase in glucose uptake stimulated by the globular domain of adiponectin in primary rat adipocytes. Diabetes 52 1355-1363.

Yamauchi T, Kamon J, Waki H, Terauchi Y, Kubota N, Hara K, Mori Y, Ide T, Murakami K, Tsuboyama-Kasaoka N et al. 2001 The fatderived hormone adiponectin reverses insulin resistance associated with both lipoatrophy and obesity. Nature Medicine 7 941-946.

Yamauchi T, Kamon J, Minokoshi Y, Ito Y, Waki H, Uchida S, Yamashita S, Noda M, Kita S, Ueki K et al. 2002 Adiponectin stimulates glucose utilization and fatty-acid oxidation by activating AMP-activated protein kinase. Nature Medicine 8 1288-1295.

Yamauchi T, Kamon J, Ito Y, Tsuchida A, Yokomizo T, Kita S, Sugiyama T, Miyagishi M, Hara K, Tsunoda M et al. 2003 Cloning of adiponectin receptors that mediate antidiabetic metabolic effects. Nature 423 762-769.

Yoon MJ, Lee GY, Chung JJ, Ahn YH, Hong SH \& Kim JB 2006 Adiponectin increases fatty acid oxidation in skeletal muscle cells by sequential activation of AMP-activated protein kinase, p38 mitogenactivated protein kinase, and peroxisome proliferator-activated receptor alpha. Diabetes 55 2562-2570.

Received 3 October 2006

First decision 23 October 2006

Revised manuscript received 16 January 2007

Accepted 23 January 2007 